\title{
Nonimmune Fluorescent Protein Staining of Neoplasms
}

\author{
Edward K. Miller, Edward N. Willey, ${ }^{1}$ Jan E. Leestma, and John L. Riggs
}

Departments of Pathology and Epidemiology, The University of Michigan, Ann Arbor, Michigan

Received June 18, 1962

\section{INTRODUCTION}

In 1952 Weiler demonstrated with ultraviolet microscopy that anti-rat liver microsomal and mitochondrial rabbit globulin conjugated with fluorescein isocyanate became selectively attached to normal and hyperplastic rat liver but not to paradimethylamino-azobenzol-induced hepato-carcinoma within such livers. In 1956 he demonstrated similar antigenic differences between normal hamster kidney and stilbesterol-induced renal carcinoma in such kidneys by microscopic localization of fluorescing antibodies (Weiler, 1956a) and by complement fixation tests (Weiler, $1956 \mathrm{~b}$ ). In addition he noted that there was slight nonspecific staining of malignant tumors by unabsorbed fluorescent tagged antibodies. He found that it was not necessary to absorb the antibody fluorescein conjugate to prevent the usual nonspecific staining of malignant neoplasms as it was in normal tissues (Weiler, 1956a). Subsequently, Hughes et al. (1957), Louis (1957c), and King et al. (1958) showed that there is a nonimmunospecific selective binding of certain fluorochrome protein conjugates by normal, hyperplastic tissues and benign tumors which is not observed in malignant tissues. They showed a similar selective binding with different fractions of serum tagged with either fluorescein isocyanate or rhodamine isocyanate. They used gamma, beta, and alpha globulin, and albumin from different species, as well as ovalbumin upon homologous and heterologous normal, benign tumorous and malignant epithelial tissues. They consistently produced a distinguishable difference between benign and malignant tissues (Hughes and Louis 1959; King et al., 1958, 1959). The benign tissues bound the conjugated protein whereas the malignant tissues failed to do so; such a selective binding was found to exist in all of a large number of human malignant epithelial neoplasms from different organs (Hughes, 1958a; Louis, 1957a, d, 1958a-d, 1960a, b, 1961; Louis and Varasdi, 1960). Immune and nonimmune conjugated sera produced similar results without distinguishable difference between them (Hughes et al., 1957); extraction of such protein conjugates with powdered liver or bone marrow eliminated the nonspecific binding without adversely affecting immunospecific binding (King et al., 1959). In addition, experimentally induced carcinomas lost the ability to bind fluorochrome-bound proteins as they became malignant (Hughes, 1958b; Louis, 1957c), and epithelia which were cultured in vitro gradually lost such a binding ability (Louis and White, 1960).

Benign and malignant supporting tissues and neural tissue did not bind fluorochrome

1 This work was supported in part by a special fellowship BT881 from the National Institute of Neurological Diseases and Blindness, USPHS. 
protein conjugates. Recently, Nairn et al. (1960) employed the technique of Hughes and Louis (1959) and were unable to produce consistently different results between the binding of protein by benign and malignant epithelial tissue.

In our hands both fluorescein isocyanate and rhodamine isocyanate used with the technique of Hughes and Louis (1959) produced an easily recognizable, consistent difference in cytoplasmic fluorescence in unfixed (fresh) benign and malignant epithelial tissues. There was uniformly bright, nonspecific fluorescence in all benign neoplasms and normal tissues which were epithelial or parenchymatous. Malignant tumors of similar origin, on the other hand, had very slight affinity for the protein conjugate. Most of these tumors, however, stained to some slight degree even though the staining was easily recognized as different from that of the benign companion tissues in the same section.

When the same technique was employed using fluorescein or rhodamine isothiocyanate conjugated protein in place of the isocyanate conjugated protein, the results were highly variable and no consistent difference between the binding of benign and malignant epithelial cells could be demonstrated. The basis for this discrepancy in results between the thioderivatives and the parent compounds is currently under investigation. Although no systematic study was made of supporting tissues and supporting tissue neoplasms, none of those examined showed stain affinity.

\section{MATERIALS AND ME'THODS}

Human tissues were obtained from surgical specimens immediately after operation, or from surgical material received for frozen section diagnosis during the course of an operation, or from necropsies. Spontaneous and transplanted, homologous and heterologous tumors in experimental animals were also used. Normal tissue and benign or malignant tissues were cut and blocked together, quenched in isopentane cooled with liquid nitrogen, and stored in stoppered bottles at $-30^{\circ} \mathrm{C}$ until needed, but not for a period exceeding 2 weeks. Sections were cut at about $5 \mu$ thickness with either the Pierce-Slee or the Harris International Cryostat at $-20^{\circ} \mathrm{C}$. The sections were placed on wet, chemically clean microscopic slides which were precooled in a bath of absolute ethanol and dry ice at $-70^{\circ} \mathrm{C}$. The sections were dried on the slides with a fan in a $-15^{\circ} \mathrm{C}$ cold room for 1 hour. They were then ethanol substituted by immersion in $-70^{\circ} \mathrm{C}$ absolute ethanol for 15 minutes and air dried in the cold room overnight (Louis, 1957b).

Fluorescein amine (Isomer II) was converted to the corresponding isocyanate by treatment with phosgene under anhydrous conditions and conjugated with rabbit gamma globulin, rabbit whole serum, horse whole serum, and human whole serum according to the method of Coons and Kaplan (1950). The conjugate was dialyzed for 5 days at $-2^{\circ} \mathrm{C}$ against phosphate buffered saline at $\mathrm{pH}$ 7.2. It was stored at $-30^{\circ} \mathrm{C}$. In preparing isothiocyanate conjugates, crystalline bovine gamma globulin, bovine serum albumin, and human whole serum were conjugated with tetramethyl rhodamine isothiocyanate and fluorescein isothiocyanate in the usual manner (Riggs et al., 1960). The fluorescein conjugates of human whole serum and bovine gamma globulin were subjected to ion exchange chromatography on a diethylamino-ethyl cellulose (DEAC) column essentially following the procedure of Riggs et al. (1958). A constant $\mathrm{pH}$ of 6.3 was 
TABLE 1

ISOTHIOCYANATE - PROTEIN CONJUGATE

\begin{tabular}{|c|c|c|c|c|}
\hline \multirow[t]{2}{*}{ SPECIMEN } & \multirow[t]{2}{*}{ CONDITION } & \multicolumn{3}{|c|}{ FLUORESCENCE STAININ } \\
\hline & & + & \pm & - \\
\hline ADRENAL & metastatic carcinoma - $1^{*}$ & $4^{*}$ & & \\
\hline BLADDER & squamous cell carcinoma - 1 & I & 1 & 4 \\
\hline BRAIN & $\begin{array}{l}\text { glioma - I } \\
\text { chordoma - I } \\
\text { medu loblastoma - }\left.\right|^{*} \\
\text { metastatic carcinoma - I }\end{array}$ & $\begin{array}{l}1 \\
2 * \\
1\end{array}$ & 1 & $\mathbf{I}$ \\
\hline BREAST & $\begin{array}{l}\text { normal - I } \\
\text { adenofibroma - } 3 \\
\text { primary carcinoma - } 3\end{array}$ & $\begin{array}{l}2 \\
4 \\
1\end{array}$ & 1 & 2 \\
\hline CERVIX & squamous cell carcinoma - I & & & 8 \\
\hline COLON & $\begin{array}{l}\text { Dolyp - } 4 \\
\text { metastatic carcinoma - } 1\end{array}$ & 6 & 1 & $\begin{array}{l}1 \\
2\end{array}$ \\
\hline FALLOPIAN TUBE & normal - $1^{\bullet}$ & $6^{\circ}$ & & \\
\hline KIDNEY & $\begin{array}{l}\text { normal - I } \\
\text { transitional cell carcinoma - } 2\end{array}$ & 5 & $\begin{array}{l}1 \\
1\end{array}$ & $\begin{array}{l}1 \\
3\end{array}$ \\
\hline LARYNX & primary carcinoma - I & & & 3 \\
\hline LIVER & $\begin{array}{l}\text { normal - } 3 \\
\text { primary carcinoma - I } \\
\text { metastatic carcinoma }-17^{*}, 1\end{array}$ & $\begin{array}{l}3^{*}, 14 \\
4 \\
68^{*}, 1\end{array}$ & 1 & 2 \\
\hline LUNG & $\begin{array}{l}\text { primary carcinoma }-2^{*}, 4 \\
\text { metastatic carcinoma }-i\end{array}$ & $6^{*}, 2$ & 2 & $\begin{array}{l}6 \\
1\end{array}$ \\
\hline LYMPH NODE & $\begin{array}{l}\text { hyperplasia - } 1 \\
\text { metastatic carcinoma - } 1\end{array}$ & 1 & 1 & 3 \\
\hline OMENTUM & metastatic carcinoma - I & 1 & $\mathbf{I}$ & 1 \\
\hline
\end{tabular}

maintained and fractions were eluted by a stepwise increase of sodium chloride molarity. The eluates tested in the staining procedure consisted of fractions obtained at the following molarities of $\mathrm{NaCl}$ with $.0175 M$ phosphate buffer: $0.15 M, 0.20 M$, $0.25 M$, and $0.30 M$. Upon dialysis of the conjugated bovine gamma globulin and human whole serum with $.0175 \mathrm{M}$ phosphate buffer, a flocculant precipitate formed; this precipitate was removed by centrifugation, redissolved in phosphate buffered saline at $\mathrm{pH} \mathrm{7.4,} \mathrm{and} \mathrm{used} \mathrm{as} \mathrm{such} \mathrm{in} \mathrm{the} \mathrm{staining} \mathrm{procedure.}$

In addition to these conjugates and their fractions, several commercial preparations were utilized. Goat anti-human gamma globulin tagged with fluorescein isothiocyanate and rhodamine isothiocyanate bovine albumin ${ }^{2}$ were employed. The fluorescein preparation had been doubly absorbed with heterologous powdered tissue and crushed

2 Microbiological Associates, Inc., 4813 Bethesda Ave., Bethesda 14, Maryand. 
TABLE 1 CONT.

ISOTHIOCYANATE - PROTEIN CONJUGATE

\begin{tabular}{|c|c|c|c|c|}
\hline \multirow{2}{*}{$\begin{array}{l}\text { SPECIMEN } \\
\text { OVARY }\end{array}$} & \multirow{3}{*}{\begin{tabular}{l}
\multicolumn{1}{c}{ CONDITION } \\
cyst - I \\
primary carcinoma - I* \\
normal - I \\
metastatic carcinoma - I
\end{tabular}} & \multicolumn{3}{|c|}{ FLUORESCENCE STAININ } \\
\hline & & & $1^{*}$ & 2 \\
\hline PANCREAS & & 4 & & 2 \\
\hline PARATHYROID & normal - 1 & 1 & & \\
\hline PLACENTA & normal - I & 3 & & I \\
\hline PROSTATE & primary carcinoma - 1 & & & 1 \\
\hline SALIVARY GLAND & mixed tumor - 2 & 3 & 1 & 1 \\
\hline SKIN & $\begin{array}{l}\text { normal }-1^{*} \text {, I } \\
\text { squamous cell carcinoma - I } \\
\text { melanoma }-1^{*}\end{array}$ & $\begin{array}{l}12^{*}, 1 \\
4^{*}\end{array}$ & $2^{*}$ & 8 \\
\hline SMALL INTESTINE & metastatic carcinoma - I & & I & 3 \\
\hline SOFT IISSUES & $\begin{array}{l}\text { rhabdo myosarcoma - } 1 \\
\text { malignant teratoma - } 1 \text { * }\end{array}$ & $2^{*}$ & & 3 \\
\hline THYROID & $\begin{array}{l}\text { nodule - } 1 \\
\text { adenoma - 1 } \\
\text { Hashimoto's - } 2 \\
\text { primary carcinoma - } 1\end{array}$ & $\begin{array}{l}2 \\
3\end{array}$ & 1 & $\begin{array}{l}1 \\
3 \\
2 \\
4\end{array}$ \\
\hline $\begin{array}{l}\text { EXPER IMENTAL ANI } \\
\text { TUMORS }\end{array}$ & Walker 256 carcinosarcoma (rat) - 1 & 6 & & \\
\hline
\end{tabular}

- AUTOPSY MATERIAL

suspensions of cultured tissue, but the rhodamine preparation was not absorbed. Prior to use, the fluorescent conjugates were extracted with ethyl acetate to remove unbound fluorochrome derivatives (Dineen and Ada, 1957). The sections were stained with the extracted conjugate for 20 minutes and rinsed 10 minutes in three changes of $0.01 M$ phosphate buffered saline at $\mathrm{pH} \mathrm{7.4.} \mathrm{The} \mathrm{tissues} \mathrm{were} \mathrm{examined}$ without a coverslip by a Zeiss photomicroscope equipped with an HBO 200 mercury vapor UV source. Two BG 12 excitor filters ( $3 \mathrm{~mm}$ and $4 \mathrm{~mm}$ ) and either an OG1 barrier filter or a combination Euphos and Wratten G-15 barrier filter were used with a 0.64 numerical aperture dark field condensor. Photographs were made by 4-minute exposures on $35 \mathrm{~mm}$ type B high speed Ektachrome color film, usually at 40 to 64 magnification. These were copied with Adox KB 14 panchromatic film 1:1 and enlarged to 160 to 500 power for publication. In each case benign and maligant tissues were blocked and cut together so that there were identically treated companion sections which could be visually and photographically compared. However, with some specimens no benign or malignant control tissue was available so the 
appropriate tissue was selected from previously stored specimens and blocked with the specimen itself prior to sectioning. After observations with the fluorescence microscope the sections were fixed in formol-saline and stained with hematoxylin and eosin so that bright field comparison could be made.

\section{RESULTS}

A series of 362 specimens was examined and three, four, or occasionally more sections from each were prepared. Table I shows the results obtained with 262 cases treated with fluorescein and rhodamine isothiocyanate preparations. Despite approximately equal conjugation of fluorochrome, the isothiocyanate preparations produced less nonspecific fluorescence than did the isocyanate preparations. In some instances staining was sufficiently weak that difficulty was experienced in trying to differentiate between the Huorochrome and the autofluorescence of elastic tissue and keratin. Even so, many malignant neoplasms fluoresced like benign companion tissues, although no neoplasms were more brilliant than their benign counterparts. A series of conjugated protein fractions was examined and the whole serum produced brighter staining than any of the fractions, no one of which showed any special concentration or selectivity of nonimmunospecific conjugated reactive material. The commercial goat anti-human gamma globulin which had been absorbed with heterologous human tissue had very little nonspecific fluorescence. The commercial rhodamine bovine albumin conjugate, however, gave nearly uniformly bright fluorescent staining of all benign or malignant tissues. Material collected from necropsies was generally unsatisfactory. The minimal interval from death until the tissue was quenched was 2 hours; with increasing periods of autolysis there was progressively lessened specificity of protein binding, immaterial of whether the isocyanate or isothiocyanate conjugates were utilized. With increasing length of time, the appearance of nuclear fluorescence was noted in both benign and malignant tissues with a progressively decreasing cytoplasmic fluorescence. Similarly fresh-frozen tissues stored for more than 2 weeks had nuclear fluorescence and progressively diminishing cytoplasmic fluorescence, even though they were stored at $-30^{\circ} \mathrm{C}$. Presumably, blocks could be stored lunger at $-70^{\circ} \mathrm{C}$; however, in this study material over 2 or 3 weeks old was simply eliminated after several preliminary trials showed deterioration of such specimens. Possibly the inability of some workers to reproduce the results of Hughes and Louis (1959) is the result of such autolysis in stored tissue.

Table II shows the results with a series of 100 tissues treated with fluorescein isocyanate conjugated horse and rabbit serum. Twelve of these were necropsy tissues and they reacted unlike the remainder which were surgical specimens. In the surgical tissue which was promptly processed we invariably found a striking evident loss of fluorochrome protein binding affinity in the cytoplasm of malignant cells, although benign companion tissue on the same slide had uniformly bright cytoplasmic fluorescence (Figs. 1, 4, 7, and 8). This difference could not be attributed to any loss of cytoplasmic bulk in the malignant cells because such cells frequently had abundant cytoplasm and the malignant neoplasms had giant plasmodial elements with far more cytoplasm than the benign cells. Occasionally there was a diffuse, very pale, general background staining which faded rapidly with UV light exposure. This diffuse staining 
did not produce any difficulty in distinguishing the considerably more prominent selective staining which permitted the ready differentiation of benign from malignant tissue. Necrotic areas in which the cells had begun to disintegrate frequently showed brilliant fluorescence. Polymorphonuclear leucocytes and macrophages also showed

TABLE 2

ISOCYANATE - PROTEIN CONJUGATE

\begin{tabular}{|c|c|c|c|c|}
\hline \multirow[t]{2}{*}{ SPECIMEN } & \multirow[t]{2}{*}{ CONDITION } & \multicolumn{3}{|c|}{ F LUORESCENCE STAINING } \\
\hline & & + & \pm & - \\
\hline ABDOMINAL WALL & metastatic carcinoma - I & & & 3 \\
\hline ADRENAL & $\begin{array}{l}\text { normal - I } \\
\text { cortical adenoma - } 1 *\end{array}$ & 2 & & $1 *$ \\
\hline BREAST & $\begin{array}{l}\text { fibrocystic disease }-1 \\
\text { adenofibroma - } 1 \\
\text { primary carcinoma - I }\end{array}$ & $\begin{array}{l}1 \\
3\end{array}$ & & 1 \\
\hline CERVIX & primary carcinoma - I & & & 1 \\
\hline COLON & $\begin{array}{l}\text { normal - I } \\
\text { polyp }-4\end{array}$ & $\begin{array}{l}10 \\
4\end{array}$ & & \\
\hline KIDNEY & $\begin{array}{l}\text { normal - }\left.\right|^{*} \\
\text { melastatic carcinoma - }\left.\right|^{*}\end{array}$ & $\begin{array}{l}2^{*} \\
2^{*}\end{array}$ & & \\
\hline LIVER & $\begin{array}{l}\text { normal - I } \\
\text { metastatic carcinoma }-4^{*}, 3\end{array}$ & $\begin{array}{l}1 \\
2^{*}\end{array}$ & & $2^{4}, 5$ \\
\hline LUNG & $\begin{array}{l}\text { normat - } 1 \\
\text { primary carcino ma - } 4 \\
\text { metastatic carcinoma - } 1\end{array}$ & I & & 11 \\
\hline LYMPH NODE & $\begin{array}{l}\text { hyperplasia - I } \\
\text { metastatic carcinoma - } 2\end{array}$ & 1 & & 3 \\
\hline SKIN & normal - $1^{*}$ & $2^{*}$ & & \\
\hline IHYROID & $\begin{array}{l}\text { normal }=4 \\
\text { nodule }-4\end{array}$ & $\begin{array}{l}4 \\
4\end{array}$ & & \\
\hline $\begin{array}{l}\text { EXPERIMENTAL ANIMAL } \\
\text { TUMORS }\end{array}$ & $\begin{array}{l}\text { human choriocarcinoma } \\
\text { (hamster) - I } \\
\text { human embryonal carcinoma } \\
\text { (hamster) - I } \\
\text { hamster melanoma (homotransplant) - } 1 \\
\text { primary mammary tarcinoma, } \\
\text { spontaneous (mouse) - I } \\
\text { secondary mammary carcinoma, } \\
\text { spontaneous (mouse) - I } \\
\text { normal organs (skin, kidney, pancreas, } \\
\text { liver, intestine, bronchi) (mouse) } \\
\text { normal organs (hamster) }\end{array}$ & $\begin{array}{l}16 \\
7\end{array}$ & & $\begin{array}{l}2 \\
3 \\
2 \\
1 \\
1\end{array}$ \\
\hline
\end{tabular}

"AUTOPSY MATERIAL

marked fluorescence. Even so, the architecture of such necrotic or purulent areas permitted their ready recognition and in no instance was there any confusion as to what they were.

\section{DISCUSSION}

No consistent histologic, chemical, or functional difference between benign and malignant tissues has yet been recognized. The application of a single criterion which has a high degree of accuracy in distinguishing between benign and malignant epithelia has repeatedly been sought without success. In our hands the technique 
of Hughes and Louis (1959) has produced encouraging results. Fluorescein isocyanate conjugated proteins stained normal and benign epithelia but not malignant epithelia. However, with the substitution of isothiocyanate, the technique produced equivocal results. A comparison of the results obtained with isocyanate and isothiocyanate can be seen in Table III. The reason for this disparity is not clear. King referred to the

TABLE 3

SUMMARY CHART

\begin{tabular}{|c|c|c|c|c|c|c|c|c|}
\hline SURGICAL SPECIMENS & \multicolumn{4}{|c|}{ Benign } & \multicolumn{4}{|c|}{ Malignant } \\
\hline Fluorescent Staining & + & \pm & - & $\%+$ & + & \pm & - & $\%-$ \\
\hline Isocyanate & 54 & 0 & 0 & 100 & 0 & 0 & 34 & 100 \\
\hline Isothiocyanate & 50 & 5 & B & 73 & 17 & II & 56 & 67 \\
\hline AUTOPSY SPECIMENS & \multicolumn{4}{|c|}{ Benign } & \multicolumn{4}{|c|}{ Malignant } \\
\hline Fluorescent Staining & & \pm & - & $\%+$ & + & \pm & - & $\%-$ \\
\hline Isocyanate & 4 & 0 & 2 & 67 & 4 & 0 & 2 & 67 \\
\hline Isothiocyanate & 21 & 2 & 0 & 91 & 86 & I & 0 & 0 \\
\hline
\end{tabular}

use of isothiocyanate without indicating any such discrepancy, but the extent to which it was employed was not stated (King, personal communication).

From preliminary experiments it appears that staining takes place through a reaction with soluble cytoplasmic constituents (Nairn et al., 1960). The process of fluorescein conjugation produces a loss of free amino groups (Creech and Jones, 1941; Hopkins and Wormall, 1933), with a shift of the isoelectric point toward a more acidic state. It has been thought that the binding of such fluorescein isocyanate conjugated protein is the result of a protein-protein physiochemical interaction with the normal basic cytoplasmic proteins (Hughes, 1958b; King et al., 1959). Depletion of this basic cytoplasmic protein in malignant neoplasms may account for the loss of the expected binding property which is found in normal cells. It has further been postulated that malignant tissuc failed to bind the protein through lack of the slowly moving $h_{*}$ proteins (characterized by Sorof and Cohen, 1951) which are present in normal tissues and which are the binding site of amino-azo dye carcinogens (Sorof, 1958: Sorof and Cohen, 1951). Such a hypothesis is consistent with the protein depletion theory of carcinogenesis advanced by Miller and Miller (1947, 1955). These hypotheses are currently under investigation in an effort to determine the nature of this alteration which occurs in malignant transformation.

The technique of Hughes and Louis (1959), as it is now employed, is far too cumbersome to permit routine use as a diagnostic test for malignant neoplasms. The procedure requires expensive equipment and is time-consuming. Work is in progress to overcome these disadvantages, but at present this method cannot be consicered to be immediately practical. 


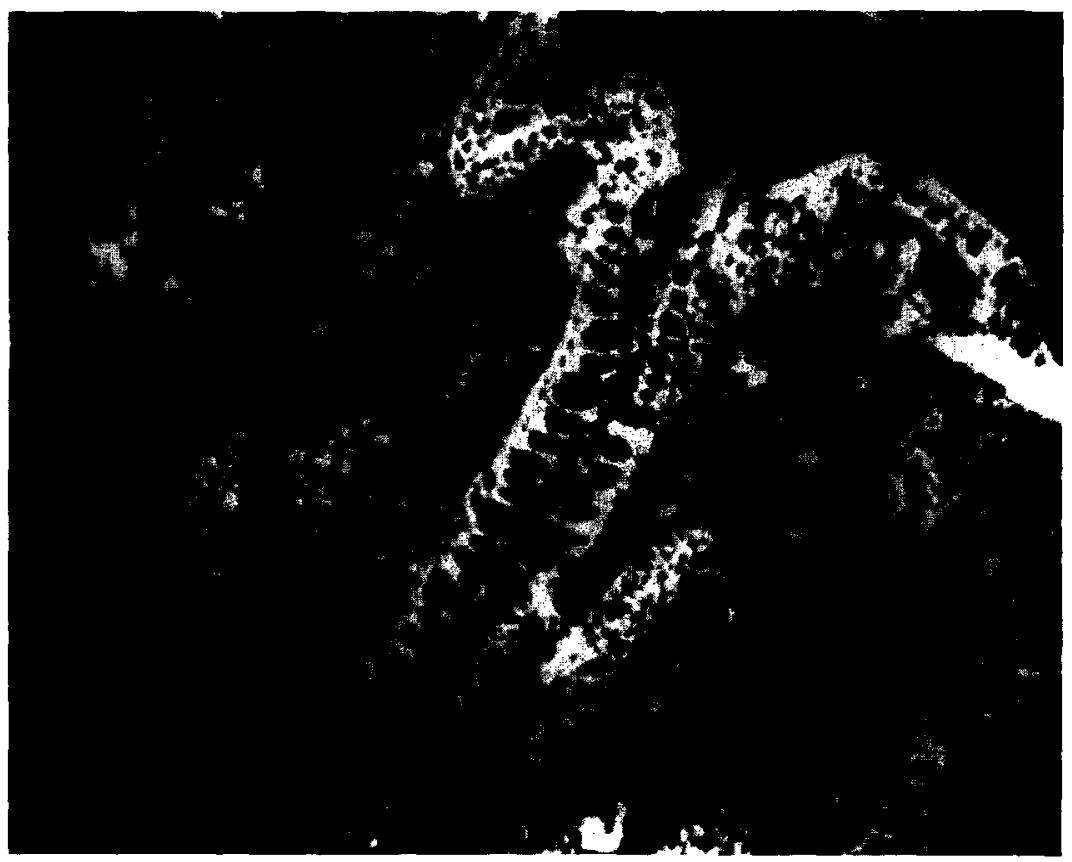

FIG. 1. Human colonic mucosa. Normal control for Fig. 3. Fluorescein isocyanate stain, $\times 256$

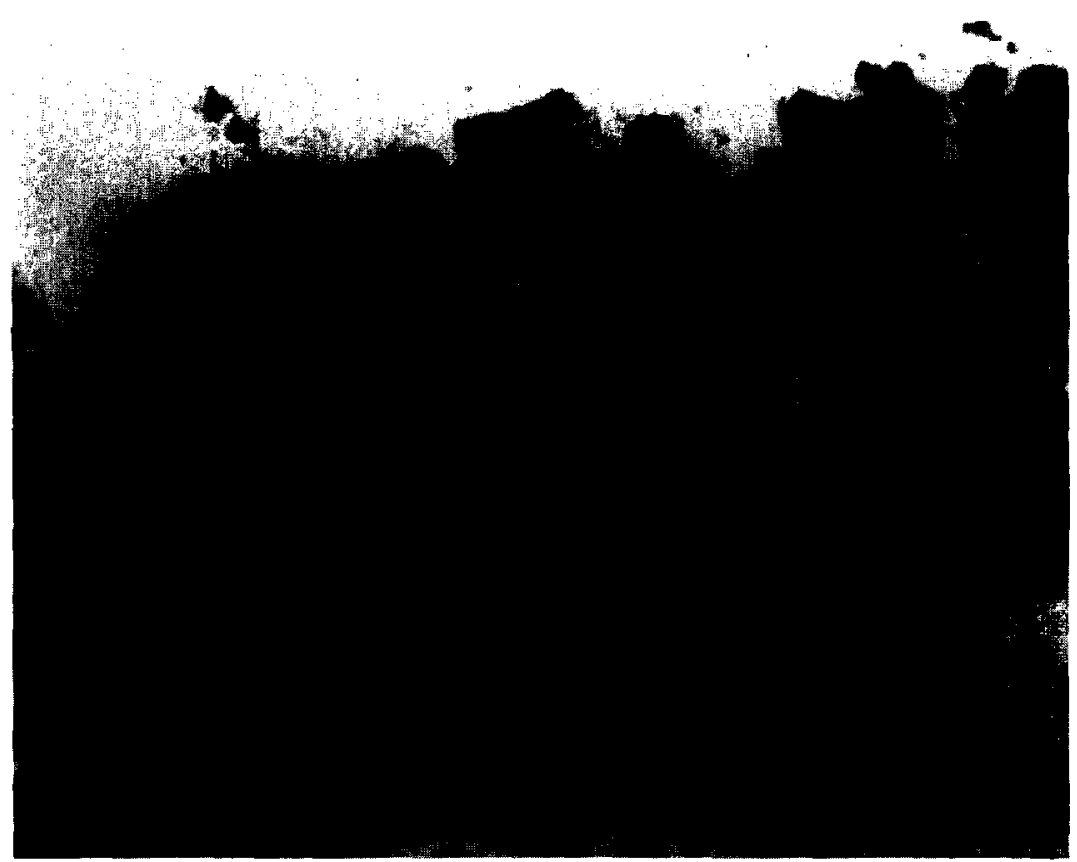

$\vec{F}$ IG. 2. Same as Fig. 1 (scrial section). Hematoxylin and eosin stain, $\times 160$. 


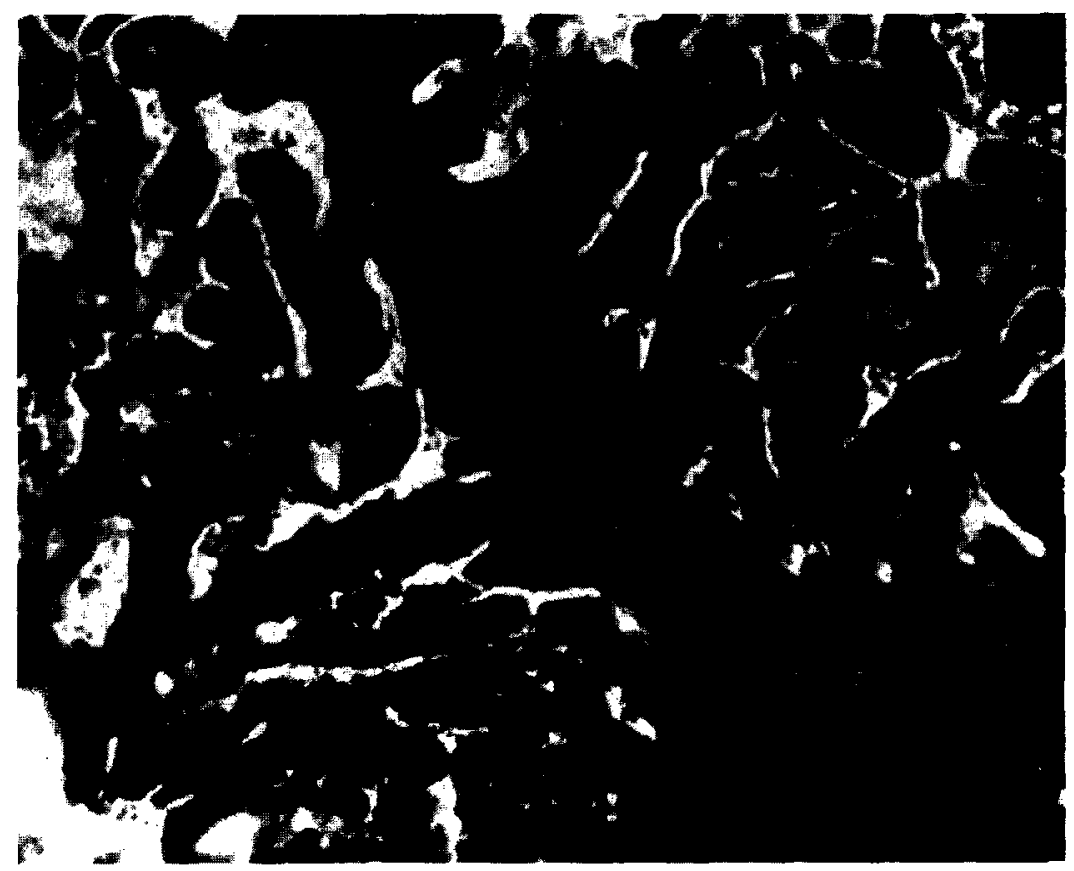

Fic. 3. Metastatic adenocarcinoma of colon. Hematoxylin and eosin stain, $\times 160$. No fluorescence was exhibited with fluorescein isocyanate stain.

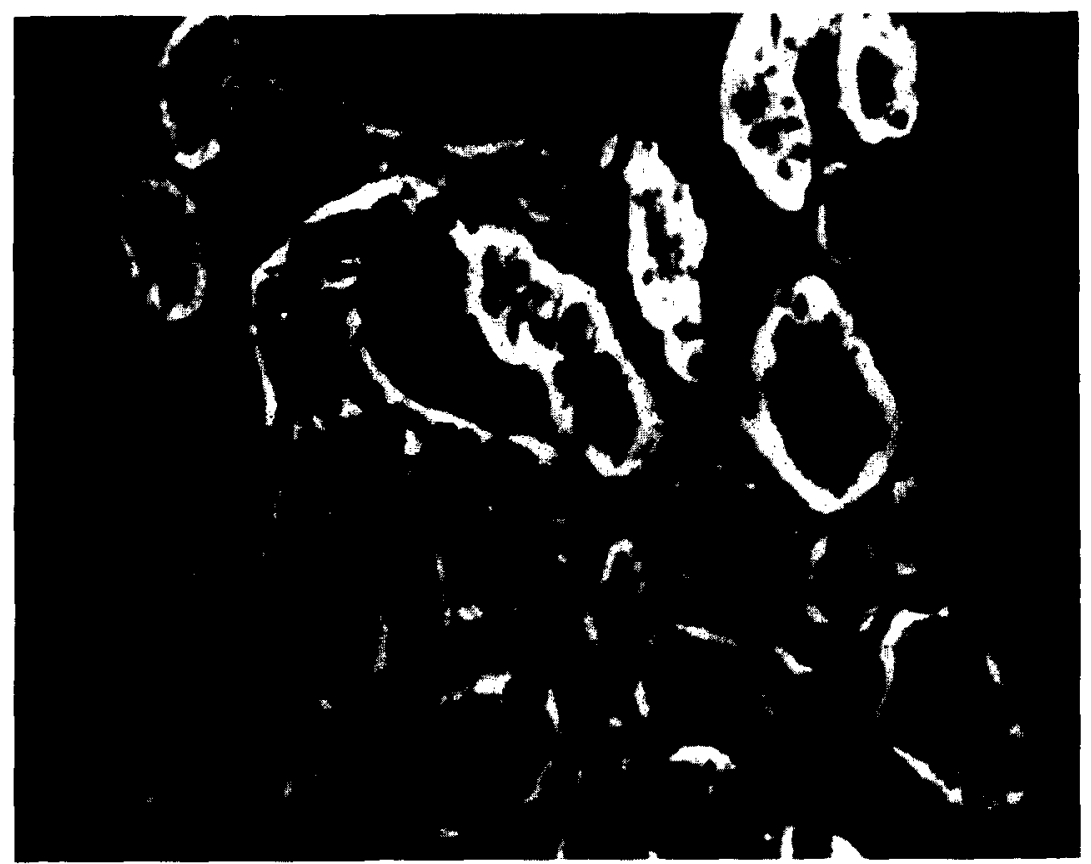

FIG. 4. Hamster kidney. Normal control for Fig. 6. Fluorescein isocyanate stain, $\times 500$. 


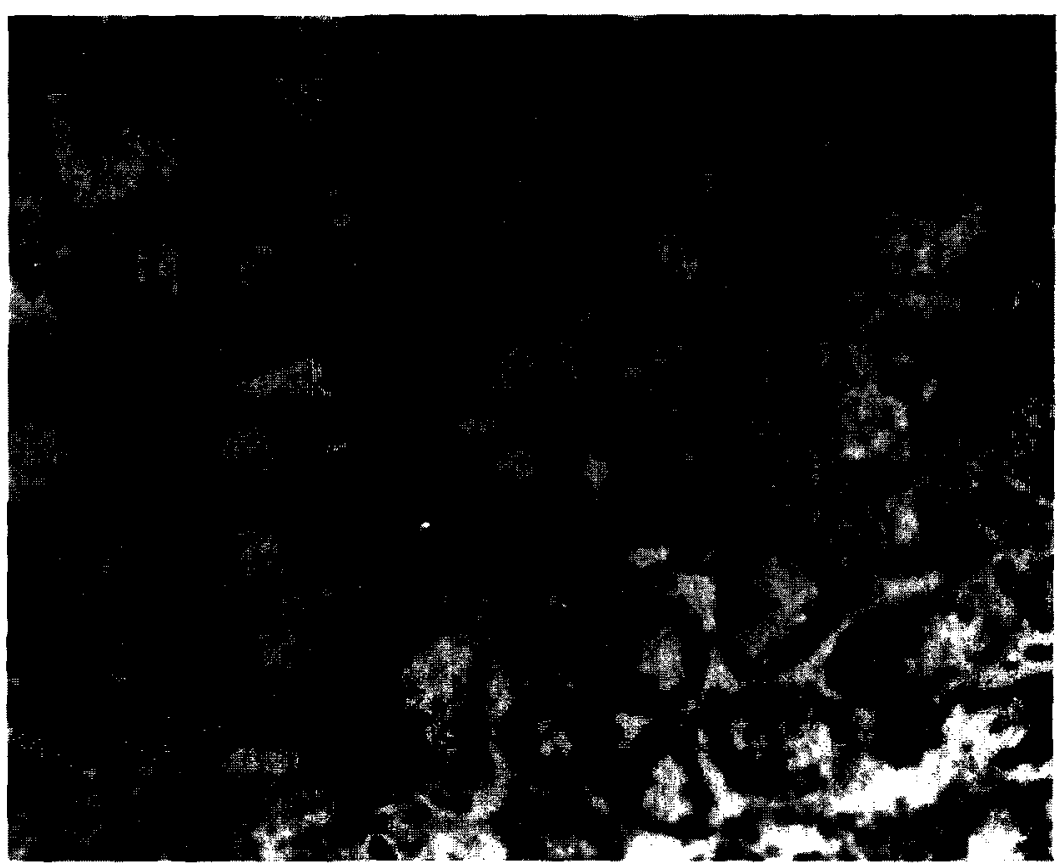

FIG. 5. Same as Fig. 4 (serial section). Hematoxylin and eosin stain, $\times 400$.

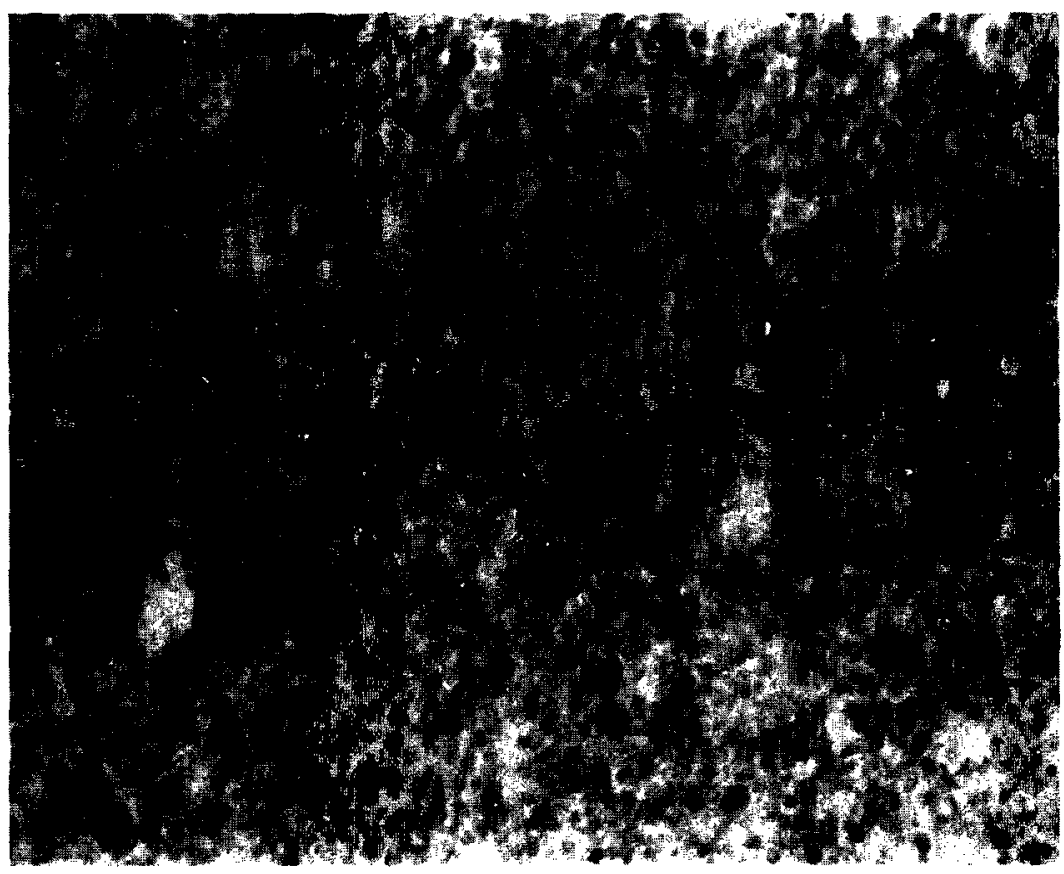

FIG. 6. Hamster melanoma (homotransplant) Hematoxylin and eosin stain, $\times 256$. No fluorescence was exhibited with fluorescein isocyanate stain. 


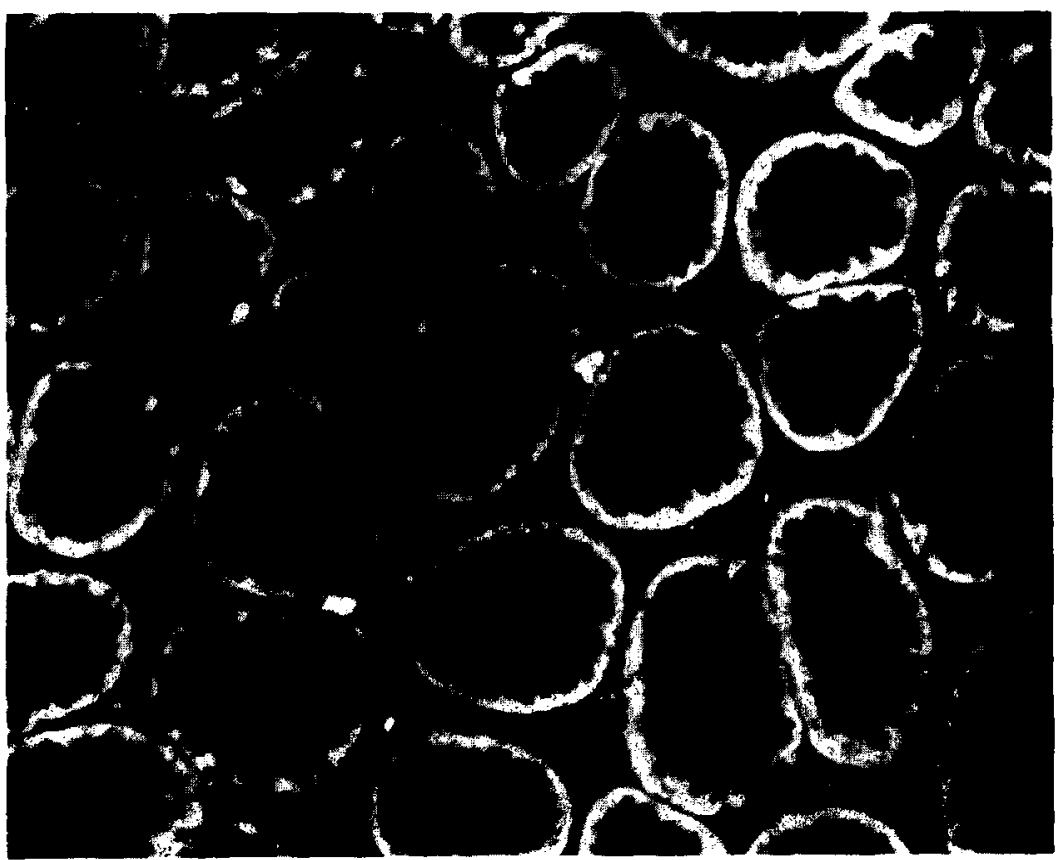

FIG. 7. Human adenomatous colonic polyp. Fluorescein isocyanate stain, $\times 350$.

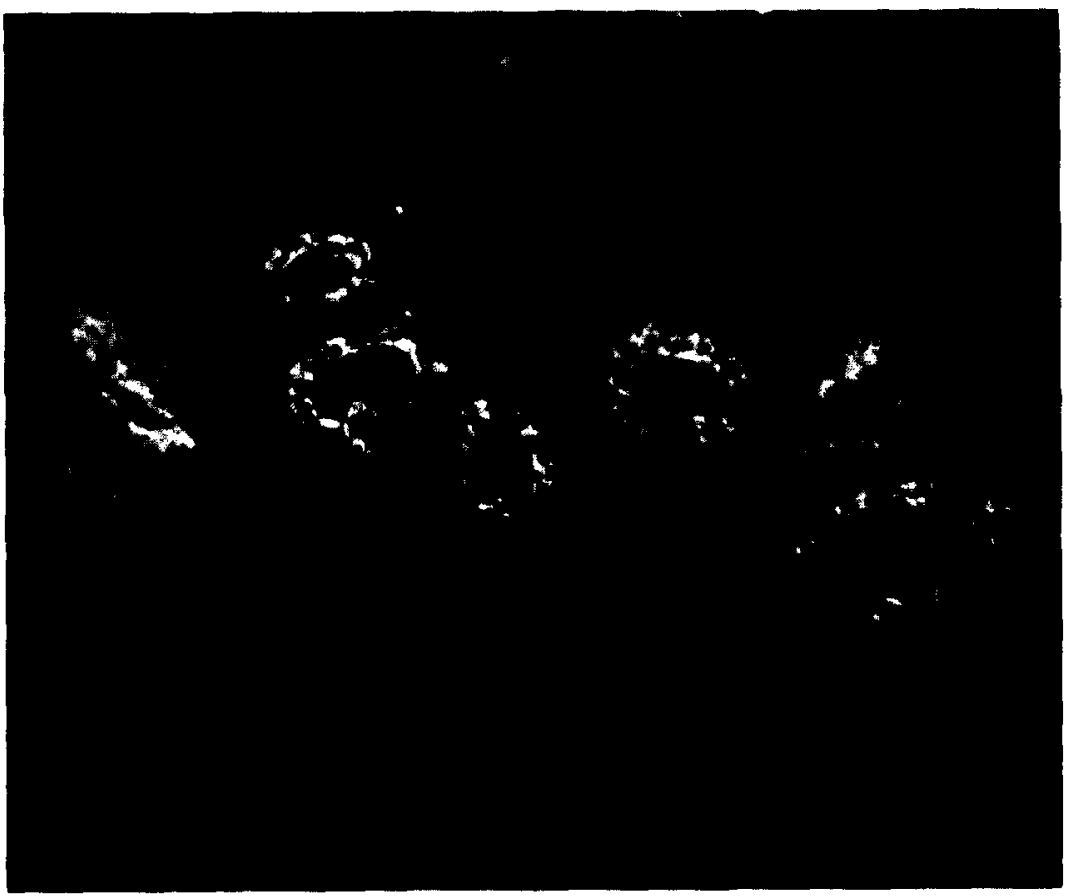

Ftr. 8. Human adenofibroma of breast. Fluorescein isocyanate stain, $\times 256$. 


\section{SUMMARY}

The nonimmunospecific tissue binding of protein-fluorochrome conjugates has been investigated. Such binding was specific in attachment to benign tissue, excluding malignant tissue, when fluorescein or rhodamine isocyanate was used according to the methcd of Hughes and Louis (1959). When fluorescein or rhodamine isothiocyanate was substituted, no such selectivity was demonstrated.

\section{REFERENCES}

Coons, A. H., and Kaplan, M. H. (1950). Localization of antigen in tissue cells. II. Improvements in a method for the detection of antigen by means of fluorescent antibody. J. Exptl. Med. 91, 1-13.

CREeCH, H. J., and JonEs, R. N. (1941). The conjugation of horse serum albumin with isocyanates of certain polynuclear aromatic hydrocarbons. J. Am. Chem. Soc. 63, 1661-1669.

Dineen, J. K., and ADA, G. L. (1957). Rapid extraction with ethyl acetate of free fluorescein derivatives from fluorescein isocyanate-globulin conjugates. Nature 180, 1284.

Hopkins, S. J., and Wormall, A. (1933). Phenyl isocyanate protein compounds and their immuno'ogical properties. Biochem. J. 27, 740-753.

Huches, P. E. (1958a). Fluorescein-globulin affinities for red cells in haemolytic anaemia. Austra'asian Ann. Med. 7, 228-234.

Hugres, P. E. (1958b). The significance of staining reactions of pre-neoplastic rat liver with fluorescein-globulin complexes. Cancer Res. 18, 426-4.32.

Hughes, P. E., and Lours, C. J. (1959). Differential staining of normal and neoplastic tissue with fluorescein-egg albumin. A.M.A. Arch. Pathol. 68, 508-512.

Hughes, P. F., Louts, C. J., Dinefn, J. K., and Spector, W. G. (1957). The role of organspecific antigen during 4-dimethylaminoazobenzene carcinogenesis of the rat liver. Nature 180 , 289-290.

KING, E. S. J. (1962). Personal communication.

KING, E. S. J., Hughes, P. E., and Lovis, C. J. (1958). The species non-specificity of globulins in the globulin-fluorescein staining of tissues. Brit. J. Cancer 12, 5-13.

Kins;, F. S. J., Hurifes, P. F., and Lours, C. J. (1959). Differential fluorescence staining of normal and neoplastic tissues: use of various serum proteins. Cancer 12, 741-752.

Louis, C. J. (1957a). A study of carcinoma of the colon using an histochemical technique. A ustralian Neve Zealand $I$. Surg. 27, 146-154

Louis, C. J. (1957b). Cutting unfixed frozen sections for fluorescence antibody studies. Stain Technol. 32, 279-282.

Louis, C. J. (1957c). Histachemical differences between regenerating and neoplastic rat liver. Austra!asian Ann. Med. 6, 277-281.

Lours, C. J. (1957d). The nature of leukaemia. I. A histochemical study of the leukaamic cell in man. Australasian Ann. Med. 6, 300-310.

Lovis, C. J. (1958a). Investigation of tumors of the skin (epidermis) using a histochemical technique. Surg. Gynecol. Obstet. 107, 317-326.

Jouts, C. J. (1958b). The nature of leukaemia. II. A histochemical study of the leukaemic cell in the experimental animal. Australasian Ann. Med. 7, 219-227.

Lours, C. J. (1958c). The significance of the cell type in the fluorescein-globulin staining of tissues. Brit. J. Cancer 12, 537-546.

Louts, C. J. (1958d). Tumours of the breast: A study employing a histochemical technique. Brit. J. Surg. 46, 147-155.

Iorts, C. J. (1960a). A historhemical study by fluorescence technique of the epithelial tumors of the cervix and uterus. Am. J. Obstet. Gynecol. 79, 336-345.

Lovis, C. J. (1960b). Fluorescein-globulin affinities of the Shope papilloma. Brit. J. Cancer 14, 216-223.

Louis, C. J. (1961). Fluorescein-globulin staining of tumor transplants. Arch. Pathol. 72, 593-598.

Louis, C. J., and Varasdi, G. (1960). Fluorescein-protein (globulin) affinities of tumors of the thyroid gland. Ann. Surg. 152, 795-803. 
LouIs, C. J, and WhIte, J. (1960). Fluorescein-globulin staining of cells in tissue cultures. Lab. Invest. 9, 273-282.

Miller, E. C., and Miller, J. A. (1947). The presence and significance of bound aminoazo dyes in the livers of rats fed p-dimethylaminoazobenzene, Cancer Res. 7, 468-480.

Miller, E. C., and Miller, J. A. (1955). Biochemical investigations on hepatic carcinogenesis. J. Natl. Cancer Inst. 15, 1571-1590.

Nairn, R. C., Richmond, H. G., and Fothergill, J. E. (1960), Differences in staining of normal and malignant cells by non-immune fluorescent protein conjugates. Brit. Med. J. 2, 1341-1343.

Riggs, J. L., Seiwald, R. J., Burckhalter, J. H., Downs, C. M., and Metcalf, T. G. (1958). Isothiocyanate compounds as fluorescent labeling agents for immune serum. Am. J. Pathol. 34, 1081-1097.

Riggs, J. L., Loh, P. C., and Eveland, W. C. (1960). A simple fractionation method for the preparation of fluorescein-labeled gamma globulin. Proc. Soc. Exptl. Biol. Med. 105, 655-658.

SORof, S., and Cohen, P. P. (1951). Electrophoretic and uitracentrifugal studies on the soluble proteins of various tumors and of livers from rats fed 4-dimethylaminoazobenzene. Cancer Res. 11, 376-382.

Sorof, S., Young, E. M., and Ott, M. G. (1958). Soluble liver h proteins during hepatocarcinogenesis by aminoazo dyes and 2-acetylaminofluorene in the rat. Cancer Res. 18, 33-46.

WeILER, E. (1952). Die Anderung der serologischen Organspezifitat beim Buttergelb-Tumor der Ratte im Vergleich zu normaler Leber. Z. Naturforsch. 7B, 324-326.

WeILER, E. (1956a). Antigenic differences between normal hamster kidney and stilboestrol induced kidney carcinoma: histological demonstration by means of fluorescing antibodies. Brit. J. Cancer 10, 560-563.

WeILER, E. (1956b). Die Anderung der serologischen Spezifitat von Leberzellen der Ratte wahrend der Cancerogenese durch p-dimethylaminoazobenzol, Z. Naturforsch, 11B, 31-38. 